\title{
Analysis on the Comparative Advantages of Developing Green Industry in Heilongjiang Province under the Labor Division Theory
}

\author{
Wenjun Zhao \\ School of Investment and Insurance, Harbin Finance University, No.65, Diantan Road, Xiangfang \\ District, Harbin City, Heilongjiang Province, China \\ 39514281@qq.com
}

\section{Keywords: Division of labor theory; Absolute advantage; Economies of scale; Green industry}

\begin{abstract}
China has made major decisions on rejuvenating northeast old industrial bases. The choice of leading industries is of crucial importance to the future economic development of Heilongjiang Province. Based on the theory of labor division with Smith, Petty and Marx, the dissertation holds that the division of labor has the function of reducing costs, improving efficiency and realizing economies of scale, so we should choose an industry with absolute superiority for production. By using this theory, the author compares and analyzes the two dominant industries of green industry and black industry in Heilongjiang Province, and thinks that Heilongjiang Province should regard green industry as the leading industry in Heilongjiang Province. Combining with the current situation of agriculture in Heilongjiang Province, some countermeasures such as reasonable and effective policies and institutional arrangement, perfecting infrastructure construction, attaching importance to technological innovation, cultivating and improving endogenous comparative advantages of agricultural products were put forward to promote the further development of economy in Heilongjiang Province.
\end{abstract}

\section{The Development of the Labor Division Theory}

Petty's Division Theory. As early as in ancient Greece, some thinkers and economists have put forward the basic ideas on division of labor such as Plato, Xenophon, and others. William Petty, the founder of classical economics at the end of the 17th century, in his book Political Arithmetick, analyzed the efficiency and cost reduction brought about by the division of labor in the textile industry and the division of labor in the shipbuilding industry, linking the division of labor with productivity growth, cost reduction and international competition. In the meantime, in the book "Re-discussing Political Arithmetic Related to Urban Growth in London," He argues that the urban growth in London benefits from the concentration and growth of manufacturing industries. The interplay and the specialization benefits of manufacturing can be achieved by focusing a manufacturing industry on a particular area. This shows that he has realized the impact of industrial agglomeration on production and economic growth caused by the division of labor.

Smith's Division of Labor Theory. In his book, An Inquiry into the Nature and Causes of the Wealth of Nations, published in 1776, Smith conducted a systematic study of the division of labor. Smith made great contribution to the impact of the division of labor on the improvement of labor productivity, the causes of division of labor and the mechanism of division of labor subject to the limits of the market, and conducted an elaborate analysis, and established the important position of division of labor in economics.

Smith believes that the main reason for the creation of wealth through labor lies in the division of labor. The deepening and continuous development of the division of labor improves labor producti-vity, emphasizing that the division of labor and specialization are the sources of economic growth, and exemplifying in detail the great role of division of labor in raising labor productivity and enhancing national wealth. Smith proposed three reasons for the division of labor to raise labor productivity: First, the improvement in the proficiency of workers; second, the division of labor avoids the time lost from one type of job to another; and third, many mechanical inventions that simplify labor and reduce labor are only based on the division of labor. Smith believes that the 
deepening of the division of labor depends on the expansion of market scope, and the expansion of market scope has promoted the division of labor. The specialization of division of labor has led to technological changes and accumulation of knowledge, resulting in increasing returns.

Smith argues that the division of labor is caused by the tendency of barter, barter and exchange one thing for another thing, that is human nature in the need of goods exchange, so the state of development of the exchange determines the state of division of labor. The development situation of the difference of human ability is not the cause of the division of labor, in the sense that the division of labor is the result. At the same time, he believes that the development of exchange and the deepening of the division of labor are closely related to the scope of the market, the conditions of transport and the size of the population. Only when the market size or demand is large enough can we promote the development and refinement of the division of labor. The development of an industry is not limited to the region and the surrounding area, but also needs a broader market. However, it is not enough to rely solely on land transport. It is also possible to expand the size of the market by means of water transport and so on, so that various industries can be further improved and developed. That elaborates on this proposition: Division of labor is limited by the scope of the market.

At the same time, Smith proposed the theory of international trade that all countries take advantage of their absolute differences in production costs to carry out their international division of labor and promote common interests through free trade. He believes that if a country produces a certain product at a completely lower cost than other countries, that is, it has an absolute advantage in the production of the product, it should produce and export the product in large quantities; on the other hand, it should import it from abroad. Smith argued that all countries should follow this principle and choose their own products with absolute superiority to carry out specialized production and exchange with each other, which is good for both sides of the trade. Smith demonstrated the idea that both parties to the trade can benefit from the international division of labor and exchange. However, his theory of absolute superiority has great limitations and can not explain the trade between absolute superiority and absolute inferiority.

Marx's Division of Labor Theory. Marx's theory of division of labor mainly includes: First, he emphasized the importance of division of labor. He thought that the level of development of the productive forces of a nation was manifested as the degree of development of the ethnic division of labor. Second, he pointed out that division of labor organizations could generate collaboration. Marx believed that division of labor produced by the division of labor can produce collaboration, thereby enhancing labor productivity. Third, he analyzed the connection and difference between the division of labor within the society and the division of labor within the workshop handicraft industry. The division of labor in the workshop takes the premise of the accumulation of means of production in the hands of a capitalist; the division of labor takes the premise of the dispersion of means of production among many independent producers of goods. Social division of labor is based on the premise of labor within the factory handicraft industry. At the same time, part of the workshop handicraft industry will also have a negative effect on social division of labor and expand social division of labor. For the difference between the two, Marx believes that the concentration of means of production in the workshop handicraft industry can ensure that a certain number of workers are engaged in a particular occupation, and that part of the working hours and means of production in the society are contingent on the distribution of different labor department's optional. The one side of the conflict is precisely the concentrated manifestation of the fundamental contradi-ction that inevitably exists in the market economy of private-owned ownership in the division of labor system. Fourth, he holds that the division of labor is based on the premise that a particular economic system, especially the ownership of production materials. It is the reflection of ownership on a specific production organization. Fifth, Marx pointed out that division of labor caused the alienation problem in the process of its development. At the same time, the division of labor has made workers more and more unilateral and subordinate. With the development of this division of labor and the accumulation of capital, laborers are increasingly dependent entirely on labor, so division of labor has caused one-sided, deformity development. It makes life bound to a 
career, into a slave to the machine. Marx emphasized the alienated form of eliminating the division of labor.

Through the analysis of the division of labor theory with the Petty, Smith and Marx, we can draw the following conclusions: First, division of labor is important. Division of labor can reduce costs, improve efficiency and achieve economies of scale. Second, division of labor theory makes us clear that we should choose an industry with absolute advantages for production. Third, Division of labor is limited by the scope of the market.

\section{Industrial Comparative Analysis in Heilongjiang Province}

Heilongjiang Province is China's old industrial base and has made tremendous contributions to the country's construction and economic development. However, with the development of reform and opening up, many problems have also emerged. The backward economic development is the outstanding issue. Today, the state proposed to revitalize the northeast old industrial base, providing a golden opportunity for the development of Heilongjiang Province. For the rapid development of any regional economy, the correct choice of leading industries is crucial. When choosing the leading industries, we should avoid the same or similar leading industries and choose the special economy or the dominant economy. Therefore, the key to the economic takeoff of Heilongjiang Province lies in whether the principle of "advantage" can be highlighted when choosing the leading industries. That is, selecting the industries that have advantages in the region as the leading industries to develop and following the principles of comparative advantage development strategies to establish the industries and products in the future. From the perspective of comprehensive economic strength, Heilongjiang Province has no advantage at all in the country. Light industry is inherently deficient in Heilongjiang province, and compared with the south processing and manufacturing industries have huge gaps, but Heilongjiang is blessed with its natural resources. Resource-based industries play a decisive role in Heilongjiang Province. The industries of coal, oil, agriculture, forestry and green food relying on natural resources have always been the mainstay of Heilongjiang's economy and have comparative advantages. Petroleum and coal belong to the black industry with more serious pollution and non-renewable resources. The agriculture, forestry and green food industries belong to the green industry with renewable resources. Now compare the two industries.

Green Industry. Heilongjiang Province is rich in agricultural resources, the total cultivated land and developable land reserve resources account for more than one-tenth of the country and the soil quality is good. Heilongjiang is located in one of the three major black soil zones in the world. With large-scale agricultural production and well-developed planting industry, Heilongjiang is one of the important commodity grain production bases in the country. Livestock husbandry also occupies a considerable proportion of agriculture. Heilongjiang Province developed relatively late and the degree of resource destruction is light, so the green food industry grew rapidly. There are many famous green product brands in Heilongjiang Province, such as Hulin's green products, Wuchang rice, etc. Especially in recent years, with the continuous deepening of industrialization in the south, the land, water and air pollution in the south have been aggravated, and the demand for green products has been steadily increasing throughout the country.

Black Industry. In Heilongjiang province, the coal mine is buried deep, and the cost of mining is high, so the price advantage is not obvious, and the market demand is decreasing. Due to the strategic significance and non-renewable characteristics of petroleum, the policy of production restriction must be further carried out with the further implementation of national petroleum security strategy. However, the oil industry in Heilongjiang province is now entering the limit production stage, which has led to the continuous decrease of oil industry output in Heilongjiang province in recent years. The rapid development of petroleum industry in Xinjiang, Gansu and other places has caused a great impact on the oil industry in Heilongjiang.

Through the above analysis, we can find that if Heilongjiang province continues to develop the black industry, there will be some space, but it is not the best direction, and it is not a long-term solution. If Heilongjiang continues to develop its industry, it will not only invest a great deal of manpower and resources in developing Heilongjiang's economy, but will also cause serious 
pollution to Heilongjiang's environment. The pollution has seriously hampered the development of green agriculture with comparative advantages in Heilongjiang Province. The development of green industry not only has the comparative advantage, but also conducive to the sustainable development of economy and environment in Heilongjiang. Moreover, the economic development in Heilongiiang Province has a great geographical advantage. It is close to Russia, North Korea, Japan, South Korea. On the one hand, it is connected with the mainland and is in a geographical location with business opportunities. Therefore, Heilongjiang province should develop green industries with comparative advantages and favorable economic and environmental sustainable development according to the domestic and foreign market demand.

We will develop the intensive processing industry for agriculture and livestock products and the green food industry. We will promote the formation of a network of division of labor. We will adhere to the path of large-scale, modernized, specialized production and diversification, and sustainable development of agriculture. We will focus on the development of international trade in agricultural products. By integrating the division of labor systems at home and abroad, we will achieve a leap forward from comparative advantage to division of labor advantage, transforming from a major agricultural province into a strong province of agriculture and further boosting economic development.

\section{Countermeasures for Developing Green Agriculture in Heilongjiang Province}

Formulate Policies that Are Conducive to the Development of Green Industries. Based on the theory of division of labor mentioned above, we can start from the determinants of the advantages of agricultural products and cultivate and improve the advantages of agricultural products. It is crucial for the green industry to make the appropriate institutional arrangements to create a comparative advantage. According to the perspective of institutional economics, a reasonable institutional arrangement is conducive to reducing endogenous transaction costs and transaction efficiency, while endogenous transaction costs and transaction efficiency are important issues of endogenous comparative advantage. Therefore, on the fostering strategy of endogenous comparative advantage of agricultural products, we should focus on the development of intensive processing of agriculture, livestock and poultry products and green organic food industry. We should expand the scope of trade and trade through rational and effective institutional arrangements to promote the division of labor and specialization. A network of division of labor is formed to reduce endogenous transaction costs, improve transaction efficiency, foster endogenous comparative advantages and promote further economic development by promoting further development of division of labor and specialized production.

Improve Infrastructure Construction. According to the theory mentioned above, the division of labor is limited by the market. We can promote division of labor and promote the development of productive forces by expanding the market scope. The development of transportation and the reduction of transportation costs can enlarge the market scope and reduce transaction costs. Therefore, Heilongjiang Province should improve infrastructure construction according to the actual conditions in various places, especially to further strengthen the construction of roads, bridges, storage and communication facilities in the main producing areas of agricultural products. This will help expand the market reach, which will help shape the network of division of labor and reduce endogenous transaction costs.

Emphasis on Technological Innovation. According to the theory of division of labor, we know that we should choose the advantageous industry to develop, so we know that the advantage of green industry in Heilongjiang is the key to promote the economic development of Heilongjiang province. According to endogenous growth theory, technological innovation is the core of endogenous comparative advantage. Therefore, increasing investment in agricultural science and technology is an important guarantee for agricultural technological innovation. At present, the export of agricultural products in Heilongjiang Province is dominated by medium and low-grade products, mainly through price advantage to expand market share, and product added value is low. Agricultural production bases and leading processing enterprises should increase input in science 
and technology according to the needs of domestic and foreign markets in Heilongjiang. We should vigorously develop new products that promote high-quality varieties and marketable products, and develop various types of deep-processed agricultural products, anti-seasonal vegetables and green organic foods to improve agricultural products added value. We should deepen the division of labor network, open up the international high-end agricultural products market and foster endogenous comparative advantages through institutional innovation.

\section{Acknowledgements}

Higher Education Teaching Reform Project in Heilongjiang Province: Study on Training Mode of Finance and Economics Optimization Major in Longjiang Universities and Colleges in New Situation (Project No.SJGY20170256).

\section{References}

[1] K.H. Marx: Das Kapital (People's Publishing House, China, 2004), p.400. (In Chinese)

[2] W. Petty: Political Arithmetick (The Commercial Press, China, 2014), p.10. (In Chinese)

[3] A. Smith: An Inquiry into the Nature and Causes of the Wealth of Nations (Shanghai Joint Publishing Press, China, 2009), p.3. (In Chinese)

[4] Peng L, Xiaoping Z. Social Stratification and Cooperative Behavior in Spatial Prisoners' Dilemma Games [J]. PLOS ONE, 2015, 10(7):e0131005.

[5] H. Liu, X. Guo and Y. Qiang: Seed Science \& Technology, (2017) No.3, p.16. (In Chinese)

[6] Y. Xue: Regional Main Grain Comparative Advantage Analysis System (MS., Chinese Academy of Agricultural Sciences, China 2006), p.15. (In Chinese) 